This is an electronic reprint of the original article. This reprint may differ from the original in pagination and typographic detail.

Author(s): Eerola, Petteri

Title: $\quad$ Nurturing, breadwinning, and upbringing: paternal responsibilities by Finnish men in early fatherhood

Year: $\quad 2014$

Version:

Please cite the original version:

Eerola, P. (2014). Nurturing, breadwinning, and upbringing: paternal responsibilities by Finnish men in early fatherhood. Community, Work and Family, 17(3), 308-324. https://doi.org/10.1080/13668803.2014.933774

All material supplied via JYX is protected by copyright and other intellectual property rights, and duplication or sale of all or part of any of the repository collections is not permitted, except that material may be duplicated by you for your research use or educational purposes in electronic or print form. You must obtain permission for any other use. Electronic or print copies may not be offered, whether for sale or otherwise to anyone who is not an authorised user. 


\title{
Nurturing, breadwinning and upbringing: Paternal responsibilities by Finnish men in early fatherhood.
}

Petteri Eerola, researcher, $\mathrm{PhD}$

Family Research Centre, University of Jyväskylä

Eerola, P. (2014). Nurturing, breadwinning, and upbringing: paternal responsibilities by Finnish men in early fatherhood. Community, Work and Family, 17 (3), 308-324. doi:10.1080/13668803.2014.933774

\begin{abstract}
In the Nordic countries, including Finland, gender-balanced distribution of childcare is both the goal of family policies and nowadays also a cultural norm of parenting. Thus, in most families, the father, along with the mother, plays a considerable role in handson care. This study captures and analyzes paternal responsibilities as narrated by Finnish fathers. It draws on 32 interviews with 16 fathers conducted during the first three years of their fatherhood, and applies the method of narrative inquiry, in which narratives are understood as constructors of knowledge. The analysis yielded nurturing, breadwinning and upbringing, framed by the levels of everyday duties and comprehensive commitments, as the constituents of paternal responsibility. Probably as an outcome of the Finnish gender-equal and familistic societal atmosphere, nurturing played the focal role in the men's accounts. On the conceptual level, the results support the view that the dimension of responsibility is wholly embedded in fathering practices.
\end{abstract}

\section{INTRODUCTION}

Across the western societies, starting from around the 1980s, significant changes in men's parenting have become increasingly evident (e.g. Morgan 1996 101; Smart 2011, 43; Forste, Bartkowski \& Jackson 2009; Doherty 1998). Involved and participative fatherhood has, at least to some extent, become more widespread and also culturally more acceptable - even demanded - as the norm of male parenthood (e.g. Doucet 2006; Miller 2011). For instance, it seems clear that the traditional tasks of fathering - begetting, protecting and providing (see Coltrane 2011, 171; Parsons 1955; Benson 1968) - do not meet the expectations of contemporary fathering, as more sensitive and "hands-on" ways of involvement have become the dominant cultural conceptions of "good fatherhood" (e.g. Eerola \& Huttunen 2011). 
These shifts in cultural expectations have likely involved novel moral duties that have affected men's sense of their parental responsibilities.

The increased public interest in male parenting has been accompanied by a notable expansion of research interest (Doucet 2013), especially in the social sciences. Whereas psychologically oriented studies of father involvement and paternal engagement in early fatherhood and during the child's growth have accumulated over several decades (see Lamb 2010; Pleck 2010; Mikelson 2008), it is only recently that greater sociological research interest has been directed towards male parenting (e.g. Dermott 2008; Miller 2011; Doucet 2006). Lately, interest has also been shown in such questions as how fathers balance earning and caring (McDonald \& Jeanes 2012) and the connections between fatherhood and work in general (e.g. Brandth 2012; Miler 2011). In addition, there has been a substantial amount of research on men's share of family leaves, especially in the Nordic countries (Almqvist 2008; LammiTaskula 2008; O’Brien \& Moss 2010). However, studies on paternal responsibilities from the viewpoint of fathers have remained scarce (see Doucet 2012).

In this study, conducted in the multidimensional field of qualitative research (see LaRossa 2012), my overall aim is to capture, analyze and conceptualize the paternal responsibilities narrated by Finnish fathers during their early fatherhood. Here, paternal responsibilities refer to the responsibilities narrated by fathers themselves, as either wholly their own or shared with their spouses. The aim relates to the social and cultural context of Finland, one of the Nordic countries and an EU member state (for fatherhood in the EU, see Sigle-Rushton, Goisis \& Keizer 2013), in which men become and act as parents. The Nordic countries, commonly perceived as pioneers in gender-equal family policies (Coltrane \& Behnke 2013, 421), are characterized by extended father-care leave with high income replacement (O'Brien 2009) and a strongly held societal principle of gender equality (Forsberg 2005). These countries, in which a gender-balanced distribution of care work is both the goal of the equality politics and nowadays also a cultural norm of parenting, constitute globally rare exceptions where men can reduce their working hours or opt for parental leave after childbirth (see Smart 2011, 43). Methodologically, the study applies narrative inquiry, which has attained a high profile in qualitative social research during recent decades. Thus, the subject of the study is men's narration of what they perceive to be their paternal responsibilities, not their actual practices. The specific research question is as follows: What 
duties and practices do Finnish fathers narrate as paternal responsibilities in their early fatherhood?

\section{THEORETICAL BACKGROUND}

\section{Sketching paternal responsibility}

The morally loaded concept of parental responsibility is simultaneously both culturally defined and connected to people's identities as moral beings (e.g. Beck-Gernsheim 2000, 130; Doucet 2006, 209). Practically speaking, all over the world, parental responsibility is commonly perceived as clustering around such tasks as taking care of a child's everyday needs, providing for the child and socializing the child into society. A more theoretical way to contemplate parental responsibilities is to make a distinction between caring for and caring about (Morgan 1996, 97-98). Whereas the former concept refers to actual care work and practices, the latter inscribes emotional meanings and other "higher level" care-related content. This approach can be applied to parental responsibility, i.e. parental responsibilities both as practices and as the profound emotional engagement behind them. Nevertheless, parental responsibilities are culturally gendered in character (see Morgan 2011, 45). Although gender inequality on a more general level has narrowed across the western world during recent decades, a gap between which parental duties and responsibilities are perceived culturally as "paternal" and which are viewed as "maternal" continues to prevail. This is especially true in the case of young infants, where "hands-on" parenthood and taking care of infants needs are even today more closely identified with motherhood (e.g. Morgan 2011, 45) and breadwinning with fatherhood (Perälä-Littunen 2007).

In studies on male parental responsibilities, particular attention has been paid to the concept of father involvement. The concept, showcased by Lamb and associates (e.g. Lamb, Pleck Charnov \& Levine 1987; Pleck, Lamb \& Levine 1985) represents the father's involvement in his child and parenthood through the components of engagement, accessibility and responsibility. According to these authors (Lamb, Pleck, Charnov \& Levine 1985; Pleck, Lamb \& Levine 1985; Pleck 2010, 59) engagement refers to the father's participation in hands-on care work and physical and psychological presence, accessibility refers to being readily available for direct interaction with the child, and responsibility refers to ensuring that the child is taken care of and providing for resources for the child. Several studies have 
highlighted how both men's practices and accounts of involvement are shaped by a number of intersectional factors, such as social class, education, sexual orientation and marital status, and contextual factors, such as cultural atmosphere and social policies (e.g. Yoshida 2012; Shows and Gerstel 2009; Townsend 2002; Doherty, Kouneski \& Erickson 1998). Thus, the meaning of responsible fatherhood for the Finnish stay-at-home dad, Australian single father or US breadwinner father, might be different.

Recently, contributions to the concepts of responsibility and involvement have been made by, among others, Townsend (2002) and Doucet (2006). Townsend (2002) has portrayed "four facets of fatherhood" (in the US context) as emotional closeness, provision, protection and endowment, Doucet $(2009,84)$ has challenged Lamb's concept by taking up interaction and accessibility as dimensions of responsibility, suggesting that paternal responsibility should be considered a pervasive feature, rather than an individual component, of paternal involvement. In other words, responsibility cannot be separated from other aspects of fathering, or parenting, in general. To conceptualize responsibility in more detail, Doucet $(2006 ; 2009)$ has expanded the current readings of paternal responsibility by drawing on Ruddick's (1995) definition of maternal demands - preservation, growth and social acceptability. She has adapted Ruddick's maternal demands to those of the father in the domestic sphere under the headings of emotional, community and moral responsibility. By emotional responsibility, she refers to the preservative and protective care that, culturally, is generally attached to motherhood. According to Doucet, contemporary fathers commonly perform this kind of care (at least in western societies), as a large body of studies has attested to fathers' engagement in nurture and care work (e.g. Dienhart 1998: Doucet 2009). Community responsibility she interprets as community-based and inter-institutional responsibilities, i.e. facilitating children's growth outside the domestic sphere (Doucet 2006). Finally, moral responsibility refers to cultural conceptions of paternal responsibilities, i.e. what it means to be a good father (Doucet 2006).

Although fathers have taken a greater share in family practices, especially in child care, but also in other household duties (e.g. Doucet 2006; Miller 2011), this has not yet overtaken their extra-domestic responsibilities, i.e. breadwinning (Parsons 1955). Breadwinning as a "male duty" continues to occupy a major role both culturally and in practice (see Miller 2011; Craig \& Mullan 2010; Lammi-Taskula 2007; Shows and Gerstel 2009), as in the majority of families, final, or primary, responsibility, both at home and in nurturing, remains the task of 
mothers. Several studies (e.g. Doucet 2006; Miller 2011) have reported that reflection on and dealing with economic issues has a focal part in the lives of most fathers, as providing can be understood as psychological involvement with both the child and family (Dienhart 1998). For example, Christiansen and Palkovitz (2001) underline how providing should be considered as a form of involvement that strengthens the emotional bond between father and child.

However, as it seems that providing is not, alone, enough for responsible paternity (e.g. Yoshida 2012; Eerola \& Mykkänen 2013), achieving a proper balance between work and family is likely to become an increasingly important aspect of responsible fatherhood.

\section{Gendered parental responsibilities in the "early years"}

Throughout western societies, men's expressed desire to become more involved and "handson" with their children has increased during the past few decades (see Smart 2011, 43; Yoshida 2012). Nevertheless, men's actual practices have not changed as much as this might suggest. Consequently, parental practices and responsibilities in the early years of parenthood have retained their highly gendered character (Doucet 2009: Miller 2011). Owing to its biological basis (mainly the physical facts of pregnancy, childbirth and breastfeeding), early parenthood is not a gender-equal phenomena; on the contrary, according to Fox $(2009,6)$, parenthood in itself creates and reproduces gender more thoroughly than any other experience in most people's lives. This highlights the family as a gendered institution in which relationships and practices are profoundly gendered in multiple ways (e.g. Morgan 1996).

Fox $(2009,293,297)$ reports that, in early parenthood, both Canadian men and women describe their parental responsibilities in similar ways. However, quite soon after becoming parents, couples who earlier shared domestic duties become more conventional with respect to who does what, i.e., women take on the greater proportion of child and household care while men concentrate on the provider role, becoming the mother's assistant and the baby's playmate (Fox 2009, 293). Parental responsibilities have a relational character, however, and mothering practices shape fathering practices in families, and vice versa (Dermott 2008, 77; Doucet 2013, 298). Fox $(2009,306)$ found that among first-time parents this led quite often to a situation, where the mother "protected" her spouse from the disruptions of infant life, restricting the father's hands-on involvement with the child and narrowing his possibilities to achieve parental skills. The issue has been termed maternal gatekeeping, i.e. the mother's 
(usually unintentional) attitudes and practices, based on a cultural understanding of good motherhood that inhibits men's growth towards and equal learning of parental caring skills (Allen \& Hawkins 1999). Gatekeeping can also be considered as institutional, in that society, through maternity and child welfare clinics and parental policies, charges mothers with profound parental responsibilities, while for fathers parental responsibility is usually seen as a private choice within the family. According to Coltrane $(2011,186)$, however, "maternal thinking" (see Ruddick 1995) and the ability to respond to the infant's needs can be achieved just as sensitively by the father as the mother, providing the father has the same degree of investment in hands-on parenthood from the very beginning.

\section{Finnish context}

In Finland and the other Nordic countries, which are commonly cited as models of genderequal parenting and shared parenthood, the discourses of shared caring are strong (e.g. Lundqvist 2012,35). For example, fatherhood is a favorite topic of parental experts and family specialists, and active and caring fathers have become mainstream in television, advertising media, weekly magazines and lately, in social media. Shared caring is also supported by parental policies, as paid paternal leave is 9 weeks, maternal leave 18 weeks and negotiable parental leave 26 weeks, after which a home care allowance is paid for up to 3 years to the parent who stays home to take care of the child(ren) (see Salmi, 2012). In addition, services and support for fathers are significant goals of institutional policies. Thus, on the ideological level, hands-on caregiving is bound to good and responsible fathering in Finnish society.

Nevertheless, everyday practices depart from expressed ideals. Finnish fathers, like their Nordic colleagues, continue to be at greater liberty to decide the terms of their engagement and participation (Miller 2011, 1096), take less parental leave (Brandth 2012, Lammi-Taskula 2006; Haataja 2009; Forsberg 2005) and work significantly more hours outside the home than mothers (Miettinen \& Rotkirch 2012, 34), all of which tend to stress the mother's primary role in infant nurturing and care giving, with the father as economic provider and assistant care giver. Despite contradictions between paternal ideologies and practices, in global comparison, Finnish men can be considered to be relatively more involved in child care practices than fathers in many other countries. For example, over $80 \%$ of all fathers, and 
virtually all those living with their children, take at least a couple of weeks of paternal leave after a child is born (Haataja 2009), and engage to a significant extent in hands-on parenthood thereafter, with over $40 \%$ of all the childcare in families with small children being done by fathers (Miettinen \& Rotkirch 2012). In addition, although sharing child care equally doesn't necessarily mean equality in other domestic domains (e.g. Gatrell 2007), statistics indicate that men's share of housework in Finnish families with children up to age 6 is approximately on the same level as their contribution to child care (slightly over $40 \%$ of all housework was done by fathers) (Miettinen \& Rotkirch 2012).

\section{METHOD}

\section{Methodological background}

This qualitative study draws on narrative epistemology, applying the method of narrative inquiry, in which narratives are understood as constructors, mediators and reproducers of personal meanings and cultural conceptions. Since the "narrative turn" in qualitative research in the late 1980s, the method has received increasing attention in social and human research (e.g. Squire, Andrews \& Tamboukou 2008, 1; Riessman 2003; Loseke 2007; Hänninen 2004). The basic premise of narrativity is that telling stories is an innate and familiar way for people to produce meanings and indicate their perceptions of the world. Moreover, since personal experiences and stories interact with cultural narratives, narrative inquiry is interested in how people narrate their lives and how their narratives are connected to the wider social context (Somers 1994; Plummer 2001, 186).

Hatch and Wisniewski (1995, 116-118) describe the characteristics of narrative inquiry as focusing on the individual, being personal in research nature, adopting a practical orientation, and emphasising subjectivity. In comparison to qualitative methods in general, narrative inquiry has the advantage that it draws attention to personal experiences and at the same time enables narratives to be understood as "social acts" (Ewick \& Silbey 1995, 197) that are timely and situationally produced and interpreted in a particular social context. The method sees narratives as constructions that enable individuals to gain a sense of "reality", and to understand, expound and construe phenomena from the perspective of socially constructed reality (Bruner 1996, 122; Chase 2005, 656; Josselson 1995, 33.) Through narratives, individuals construct their lifespan as a continuum (Frank 2002), normalizing and 
"naturalizing" the experiences and events in their lives (Abbott 2002, 40) and creating coherence by linking sporadic events into meaningful wholes (Loseke 2007, 672;

Polkinghorne 1991). Thus, among the topics studied using a narrative approach, intimate topics, such as life stories and life changes, have been especially popular (e.g. Hänninen 2004; Riessman 2003). Studying life changes through narratives enables us to capture the meanings people give to the most sensitive experiences in their lives (Hänninen 2004, 76). While there is no unambiguous answer to the question "What is a sensitive topic?" (Hyden $2008,134)$, early fatherhood can be considered such an intimate topic for the vast majority of men.

In this study narrative analysis was conducted to investigate Finnish fathers' experiences of paternal responsibility in relation to prevailing cultural models. As a tool to consolidate and systematize the analysis of the narratives of paternal responsibility, I utilized the codingmethods - open, axial and selective coding - used in Straussian grounded theory (GT) approach (Strauss \& Corbin 1998; see Kelle 2007). I applied them as tools both to capture and analyze key narrative themes and dimensions of paternal responsibility and to increase the reliability of the narrative analysis. Although this might invite criticism due to differences in epistemological basis of narrative research and GT, GT is regarded as one of the most systematic qualitative research methods, and has several advantages that could fruitfully be applied more broadly within qualitative research including to narrative analysis. Corresponding approaches have been also adopted by others (e.g. Roy 2006).

\section{Data}

The empirical data of the study comprise in-depth interviews with 16 fathers, conducted by the author during 2008-2011. All the fathers were interviewed twice during the first three years of their fatherhood, and hence the total number of interviews was 32 . The first round of interviews was conducted when fathers' first-borns were from 6 months to 2 years of age. At the time, all the interviewed fathers were living in a heterosexual relationship (marital or cohabitation) with the mother of their child, which is the usual way in which men become first-time fathers in Finland and the other Nordic countries today, while other forms of fatherhood may exist at later stages of men's lives. Prior to pregnancy, the men's couple relationship with the mother of their child were from 6 months to 5 years. The second round of interviews was conducted approximately 2 years later. At that time, the fathers were aged 
from 25 to 31 years, 13 of them had fathered more children, and one had divorced and was living apart from his children although keeping regularly in touch with them. The interviewed men represented various professional fields, such as engineers, health-care specialists, students, security guards and private entrepreneurs. During the second round of interviews, 11 of the men were working full-time, 3 were full-time students and 2 were stay-at-home fathers. Ten of them held a BA- or MA-level degree (or equivalent). Overall, the men can broadly be described as middle class, though with slightly above-average education. Seven men had experience of being a stay-at-home father (from 4 months to 2 years). The interviewees were recruited through e-mailing lists of students with families, various general and family-themed internet discussion forums, and snowball sampling. As participation was voluntary, it can be assumed that only fathers who were engaged and interested in the topic participated, thereby limiting the generalizability of findings. The interviews took place, e.g., in coffee shops, homes, public libraries, and other convenient places chosen by the interviewee, and lasted for 90 minutes on average. The total data comprised over 48 hours of interview speech.

The data analysis, the dataset itself was gathered through interviews which were informed by previous research on early fatherhood. I conducted the in-depth interviews by applying the methods of the narrative and thematic interview. Whereas the first round of interviews focused on first-time fatherhood, the second round of interviews dealt with issues of everyday family life and parental practices in the post-babyhood stage. In the second interview, I encouraged the fathers to talk freely about the issues that they found personally meaningful and important, but also set some precise questions, such as "In your own words, tell me what factors make for a responsible father?"; "How do you personally fit the picture of responsible fatherhood that you have just described?" and "What, if any, do you think are the key differences between paternal and maternal responsibility?". As the interviews were informal in most of them the men produced broad narratives that went beyond the immediate issue of parenting; for example. They spoke about their couple relationship, the division of housework, working life and their lives in general. As the purpose of the study was not to describe the temporal process of engaging in responsibility, but rather to build a comprehensive picture of how fathers see their fatherhood during the "early years", my analysis, although drawing on the first interview data, focused mainly on the second interviews. Men's narratives at the onset of their fatherhood have been analyzed and reported 
earlier as part of the project of which this study forms part (see Eerola \& Huttunen 2011; Eerola \& Mykkänen 2013).

\section{Analysis}

I implemented analysis by reading and coding the interviews with the aim of finding similarities and dissimilarities between fathers' narratives. When reading the interviews, I paid special attention to the language used by the men in describing their relations with their child and their child-rearing practices, their role in the family (especially engagement in child care and household duties) and to the gendering of parental responsibilities. In this phase, I systematically coded narrative fragments and expressions that indicated divergent perspectives on paternal responsibility (open coding); thus, the narrative themes of nurturing, breadwinning and upbringing began to emerge. Next, I examined the interviews in light of the emergent themes and the interrelations between these in detail (axial coding). Finally, I interpreted the fathers' narratives according to the extent and character of responsibility (selective coding). This yielded two conceptual levels - everyday duties and comprehensive commitments - of paternal responsibility. As the interviews were conducted in Finnish, the narrative samples presented in this article have been translated into English with an aim of extracting the general sense and meanings of the narratives rather than a literal word for word translation (see Nikander 2008).

\section{RESULTS}

In this section, I present the three narrative themes of paternal responsibility - nurturing, breadwinning and upbringing - that emerged from the analysis, along with examples from the empirical data. In conclusion, I discuss the two levels of paternal responsibility - everyday duties and comprehensive commitments - that were present in all the themes.

\section{Nurturing}

The narrative theme of nurturing refers to the psychological and emotional presence and care giving of the father, and was narrated as "the basis" of paternal responsibility. Being a responsible father was profoundly tied to care-giving activities and "being there", 
emphasizing a hands-on approach to responsibility, but also its intimate character. Fathers reflected on this theme more often than on other themes.

The fathers invariably narrated their striving to be present in the child's life as comprehensively as possible. This issue has previously been described as "being there" (e.g. Palkovitz 2002; Miller 2011). In accord with earlier studies, expansion of the father's role in parenting practices during the child's growth (see Lamb 1997), interviewees stressed the importance of the father's early involvement, probably influenced by both the formal family policies in place in Finland and a father-friendly cultural atmosphere. Also, their narratives emphasised involvement as an intentional choice, underpinned by a sense of responsibility and the welfare of the child and family. For example, in Mikko's words:

I definitely try to spend as much with them as possible, as... I think it's really important for them, definitely, 'cos... I kinda think that it gives them better possibilities to get on in their lives... (Mikko, 29 years, 2 children, engineer MSc)

The fathers didn't perceive "being there" solely as a question issue of physical presence, but rather as emotional and psychological closeness, grounded in their engagement in nurturing and care work. The fathers described their roles as active parents with hands-on involvement in child care. With newborns, this applied extensively to nurturing and everyday caring practices. Several fathers also mentioned certain activities, such as changing diapers and bathing the infant, as "their duties", the mother in turn taking care of feeding the child. In the fathers' narratives, their role in taking care of the child's physical activities, such as indoor and outdoor play, became increasingly foregrounded, although tasks such as dealing with the child's regular visits to the welfare clinic were also reported. Being together with the child as an everyday practice can be seen in Paavo's narrative:

At the moment, while they're all so young, you really can't leave them even for a sec... Thus, while I'm at home I spend most of my time just being and playing with them... Going out to the park, taking them with me to shop for groceries, you know, nothing special, just the regular daily stuff... (Paavo, 31 years, 3 children, account manager)

In narrating their engagement in everyday caring practices such as feeding or clothing the child, fathers didn't make a marked distinction between paternal and maternal 
responsibilities. While some of them saw themselves as more "sensible" and "maternal" than the "average father", only a few fathers stressed that the overriding responsibility to ensure that everything was under control was the mother's. In these cases, the father saw himself as the mother's "assistant", a role also commonly found among fathers in earlier studies especially in the US context (e.g. Marsiglio \& Cohan 2000). These exceptions aside, the fathers saw their relatively active engagement in care work as advantageous to the child, and also as an expression of their willingness to share the duties of child care with the mother. Thus, it seems that the discourses of parenting experts on the importance of the father's early involvement have also influenced the men's understanding of their parental duties.

The importance of "family time" spent together with mother and child was commonly present in the fathers' narratives. More profound involvement emerged in the emphasis placed by a few fathers on the importance of private time with the child, without the mother present, on the grounds that this strengthens the father-child relationship and contributes to the ability to bear full responsibility for child care. In these accounts, the fathers' care-giving responsibilities were seen as equal with those of the mother, unconstrained by gender. This also indicates the fathers' strong desire to be comprehensively involved with their child, as illustrated in the following extract:

I think it (the stay-at-home period of over 2 years) has had a great effect on my relation with him (the first-born), we really have a close and special relationship, and, now I can really say that I know him, and how to get on with him, and... Without those years and months, I'm sure that the bond we now have wouldn't have developed, so it really means a lot to me... (Antti, 29 years, 2 children, entrepreneur)

In line with national statistics (see p. 8 above), all the men took paternal leave of from 2 to 3 weeks immediately after childbirth. Seven of them acted also as a stay-at-home father (from 4 months to 2 years) at some point during infancy; this proportion, however, is well above the average (see e.g. Haataja 2009). These men attached the taking of extended parental leave to responsible fatherhood, and emphasized the importance of taking parental leave to ensure the child experienced the care of both parents, to consolidate the father-child relationship, a nongendered duty, and, in addition, to support the mothers option of returning to working life. Although they all highlighted that the wish to take extended parental leave was their own, it was clear that their spouses also supported the idea of shared leave. Nevertheless, it seems 
that the father needed to negotiate with the mother, and gain her approval, if he wished to take extended parental leave. This suggests that, while on the policy level, family leave is the legal right of both parents, in the prevailing cultural atmosphere the mother is regarded as having the prerogative to decide who will take parental leave. According to Ismo:

Yeah, sure, we discussed it together, and, she (spouse) didn't have any problem with that at all... And it was really important for me, 'cos I just felt that it was the only right thing to do, and you know, without it I wouldn't have given my best shot as a father... (Ismo, 28 years, 2 children, software developer)

\section{Breadwinning}

Despite the narrative emphasis on the extension of paternal responsibilities into a domain traditionally perceived as maternal, the traditional understanding of breadwinning as an extradomestic paternal responsibility (see Parsons 1955) was also inscribed in the narratives, though with new content. In Finland, it seems that despite the spread of nurturing practices among fathers, providing for the family continues to be perceived as a common paternal responsibility (e.g. Palkovitz 2002; Miller 2011; Doucet 2013), even in cases where it might be in conflict with the father's expanding role as a caregiver (Miller 2011, 10).

According to the analysis, paid work and breadwinning were both seen as an important part of paternal responsibility. Providing was considered a duty that promotes the well-being of both child and family, and one that corresponds in importance to other parental duties. This is in line with the view that breadwinning is also perceived by fathers as creating an emotional bond between father and child (Christiansen and Palkovitz 2001). Probably affected by the familistic cultural atmosphere of Finland (Jallinoja 2006) that stresses the importance of "being there", other possible accounts of work were less obvious (e.g. a career-orientated approach to work was highlighted by only two fathers), suggesting a strong understanding of the role of work in securing the family's welfare. This is visible in the following extract from the interview with Pentti:

Well, I think it's a really responsible duty that I had, you know, providing for them (the family). Now she's at home with the kids, so, that my duty for sure... And I'm really proud of it, actually... (Pentti, 28 years, 2 children, nurse) 
However, the analysis points to new content in relation to the key question of breadwinning, which was no longer seen primarily as a paternal parental responsibility, even if still commonly undertaken by the father in infant families. Although at the time, with their partners on extended family leave, most of the fathers had main charge of the family's economic situation, they did not perceive this breadwinning role as father-specific, but rather as a gender-neutral duty for both parents. According to the fathers, all the families had planned that when the youngest child has reached from 18 months to 3 years of age, both parents would be working. This points to the strength of the Nordic dual-earner model.

Yeah, it's the traditional division that the father takes care of the bread and the mother the home. But for me, now when the kids are young, it really doesn't matter which of us does it (breadwinning), it's a shared duty. (Jukka, 29 years, 2 children, MA student and stay-at-home father)

At the interface of care work and breadwinning, the important issue of striking a proper balance between work and family arose (e.g. Brandth 2012). Most of the fathers felt that they had managed the situation quite well, while some found it more difficult to achieve. For example, fathers who had only worked outside the home found it more often difficult than those who had taken extended parental leave. After coming back to work, men who had personal experiences of stay-at-home fatherhood did not report significant difficulties in work-family balance. Nevertheless, as the results suggest, breadwinning retains an important position among the various Finnish paternal responsibilities, although clearly not enough to fully meet the demands of "responsible fatherhood"; rather, it was duty to be shouldered alongside nurturing and care work. In Seppo's words:

You know, this idea that a father should just feed his family... I really can't agree with it, as I don't see it as responsible at all. For me, making money doesn't have anything to do with good fatherhood, rather, being and living with them (the family), that's what's important. (Seppo 28 years, 2 children, researcher)

\section{Upbringing}


The preceding sections have described the father's responsibilities in the domestic and extradomestic contexts. However, a third theme - which I term 'upbringing' - was present in both of these. Unlike nurturing and breadwinning, which were topical issues from the beginning of parenthood, 'upbringing' appeared to be a responsibility that increased in importance with the growth of the child. Fathers stressed the importance of upbringing, especially in the moral sense. Although upbringing was not explicitly brought up by the interviewer, it featured in many interviews. Hints of a gendered understanding of responsibility for 'upbringing', even if more discreetly expressed than either nurturing or breadwinning, were present in talk on this theme.

Probably due to the relatively young age of their children, instead of teaching concrete skills, the focus of the fathers' narratives was on giving their children a moral upbringing, with an eye to the future. For example, they emphasized their duty to "teach them (children) the difference between right and wrong" (Ilkka, 30 years, 2 children, security guard, divorced) and to "raise them to be proper and reliable tax-payers" (Jouni, 28 years, 2 children, civil engineer). In several cases, this was attached to the idea of giving children an appropriate adult or male role model. According to Simo, for example:

As a father, it's my responsibility to teach him, to raise him, you know... To try to raise him to be as good a citizen as possible, and to teach him all the good values, that are important. And the only way to do that, it's to act that way myself. (Simo 26 years, 1 child, entrepreneur)

The fathers' narratives differed as to whether upbringing, especially in the moral sense, had a male-specific character or not. Since the fathers narratives dealt mainly with "traditional paternal duties", such as setting boundaries, socializing and security (see Coltrane 2011), these were not spoken of as father-specific issues. Instead, they were negotiated and implemented together with the mother, suggesting a strong understanding of joint responsibility, as also emphasized in the themes of nurturing and breadwinning. However, in a few men's accounts, a gendered narration was evident. For example, according to Mika:

For me, it's really important to set and make them (children) learn that there are certain boundaries that should not be over-stepped. And that's my job... Just like 
security issues are essential, definitely... I'm a rather protective kind of guy, and, I've been thinking about those things a lot. (Mika, 29 years, 2 children, full-time student)

\section{Responsibilities as everyday duties and comprehensive commitments}

I conclude this analysis by examining the two narrative levels of responsibilities - the level of everyday duties (e.g. feeding, clothing) and the level of comprehensive commitments (e.g. being a role model, family welfare) - which appeared in the fathers' narratives. All three narrative themes were identified on both levels, although with some differences of emphasis, as shown in Table 1 below.

TABLE 1. Paternal responsibilities in early fatherhood as everyday duties and as comprehensive commitments

\begin{tabular}{|l|l|l|l|}
\hline $\begin{array}{l}\text { Paternal } \\
\text { responsibilities in } \\
\text { early fatherhood }\end{array}$ & Nurturing & Breadwinning & Upbringing \\
\hline Everyday duties & $\begin{array}{l}\text { Everyday caring } \\
\text { practices, spending } \\
\text { time together, } \\
\text { playing }\end{array}$ & $\begin{array}{l}\text { Providing for } \\
\text { everyday needs }\end{array}$ & $\begin{array}{l}\text { Setting boundaries, } \\
\text { decision-making }\end{array}$ \\
\hline $\begin{array}{l}\text { Comprehensive } \\
\text { commitments }\end{array}$ & $\begin{array}{l}\text { Supporting the } \\
\text { child's development, } \\
\text { strengthening the } \\
\text { father-child } \\
\text { relationship }\end{array}$ & $\begin{array}{l}\text { Ensuring welfare of } \\
\text { child and family }\end{array}$ & $\begin{array}{l}\text { Acting as role model, } \\
\text { socializer and } \\
\text { providing security }\end{array}$ \\
\hline
\end{tabular}

The levels indicate the multidimensional character of paternal responsibilities. Everyday duties emphasize responsibilities as set of caring practices, conceptualized also as "caring for" by Morgan (1996). These duties illustrate hands-on tasks and practices that fathers interpreted as "responsible". On this level, the narrative theme of nurturing received special emphasis. At the level of comprehensive commitments, closely related to Morgan's concept of "caring about", paternal responsibilities were perceived as profound, psychological engagement with the child and promoting the child's development. These commitments, 
which highlighted the emotional and affective side of paternal responsibility, were also future-oriented, e.g. to make sure the children were given "a good start in life". Comprehensive commitments were narrated especially in relation to upbringing and breadwinning.

\section{DISCUSSION}

This study has presented an analysis of paternal responsibilities arising from the narratives of a small sample of Finnish men in their early years of first time fatherhood. The analysis yielded three themes of paternal responsibility within a framework of everyday duties and comprehensive commitments. Although comparable classifications have been presented previously (e.g. Townsend 2002), in these Finnish narratives, they were filled with new content. On the conceptual level, the results support Doucet (2006), who argues that responsibility is deeply embedded in fathering practices, as it is involved in everything that one does and doesn't do as a father. Thus, responsibility should be perceived as a built-in dimension of father involvement rather than as a subordinate concept. This can be applied to parental responsibilities more generally, and outside the Finnish context.

Previous studies have highlighted the gender-specific nature of paternal responsibilities, while also recognizing that, at least in western societies, men's engagement in care work has become more widespread (e.g. Doucet 2006; Miller 2011). In this Finish study, a gendered undertone was mainly absent from the narratives; instead, men's understanding of paternal duties and practices was based on gender-neutral parental responsibilities carried out together with the mother. To look no further back than the 1990s, gendered labor in childcare was evident in the accounts of Finnish fathers (see Korhonen 1999), whereas in the present study the narratives stressed responsibilities in gender-neutral manner, without essentializing "paternal" and "maternal" duties (with a few exceptions such as breastfeeding, maternal primacy in leave decisions and paternal moral authority in a few narratives). This can be seen for example in the narratives of nurturing and breadwinning, which have traditionally been highly gendered. In addition to the probable greater paternal engagement of these Finnish men compared to the national average, it is likely that the public fatherhood, parental leave and gender equality discourses, along with the familistic atmosphere, that emerged in Finnish society in the early 2000s, have promoted the idea of nurturing and breadwinning as shared and non-gendered responsibilities for both parents (see Jallinoja 2008; Jallinoja 2006; Sipilä, 
Repo, Rissanen \& Viitasalo 2010). It is also interesting that whereas, according to national statistics, Finnish fathers contribute broadly to domestic work (see "Finnish context" section above), and the interviewees also saw themselves as sharing in the housework, such as washing the dishes and doing the laundry, they didn't see these tasks as among their paternal responsibilities; instead, they viewed them on a more general level as household duties "that just have to be done". This suggests that men's understanding of paternal responsibilities is strongly embedded in the idea of the presence and direct care giving of the father.

In addition, the analysis illustrates something of the reflective character of contemporary Finnish fatherhood, as it highlighted the significant extent to which these fathers had reflected on their roles, duties and commitments as parents. This especially emerged in the broad narration of comprehensive commitments, i.e. "higher-level" responsibilities, behind actual practices. This suggests that fatherhood is not something that can be considered as selfevident and stable, but instead something that men need and want to ponder. This highlights the intentional, intimate and emotional character of fatherhood, and perhaps also points to the active discussion of fatherhood in the Finnish media, and in expert discourses perhaps providing men with words and concepts, and a cultural obligation, to reflect upon their role as fathers.

The present narrative inquiry was conducted by applying the GT coding method as a tool to consolidate and systematize the analysis. Thus in this study the two qualitative methods narrative analysis and GT - supplemented each other, the coding method enabling a systematic interpretation of both the detailed narration - the three narrative themes - and the "bigger picture" - the two narrative levels - of paternal responsibility. While there is, of course, no such thing as "pure" narrative research, discovering new ways to use the method can nevertheless advance it and produce new narrative takes on the subject. Thus, new approaches to narrative inquiry should be encouraged in the future, including in the field of family studies, as such methods can yield novel insights into parenting and daily family life.

The small study sample consisted of broadly middle-class city-dwelling men, with a slightly above-average education, so that the results apply to paternal responsibilities in a Finnish middle-class context. The question remains, whether, and to what extent, the results can be generalized to other socioeconomic groups. While engaged and nurturing fatherhood has been criticised as a phenomenon pertaining to relatively highly educated and middle-class 
men (LaRossa 1988; Dermott 2008), recent Finnish studies (Eerola \& Mykkänen 2013; Mykkänen \& Eerola 2013) suggest that nurturing fatherhood with hands-on responsibilities is widely prevalent in the accounts of first-time fathers. On the basis of the fatherhood discourses that emerged in these studies, it is conceivable that these aspects of fatherhood exist more generally, irrespective of socioeconomic status, during the first years of paternity. It is, however, likely that the fathers included in this study, because their participation was voluntary, were more engaged with their children than average Finnish fathers, and this may well introduce some bias into the results. From a more global perspective, given the cultural similarities between the Nordic societies, it is reasonable to assume that the narratives produced by the present sample of Finnish men are likely to be found among their Nordic counterparts. Corresponding discourses and narratives might be also found outside the Nordic context, but from where and to what extent, remains unclear.

The narratives that have been analyzed above are not literal portrayals of men's real-life practices. Thus it is important to remember that while the men's narratives on fatherhood might be fairly uniform, men's actual parenting practices are likely to display more variation. Also, gendered features continue to be present in Finnish parenting, as not all Finnish fathers (or their spouses) share parenting equally. However, in light of the high volume of studies on the positive effect of active and involved fatherhood on the child's development and wellbeing of the whole family (see Allen \& Daly 2009), the results are promising. As the narratives demonstrate, cultural atmosphere and social policies have an effect on men's understanding of their paternal responsibilities, and thus, offer opportunities for change in their actual practices. Consequently, investment in a father-friendly culture and policies pays off, not only in more involved narratives, but, most importantly, in more involved fathers. 


\section{References}

Allen, S. \& Daly, K. (2007). The effects of father involvement: An updated research summary of the evidence. Guelph, ON: University of Guelph, Center for Families, Work \& WellBeing.

Allen, S.M. \& Hawkins, A.J. (1999). Maternal gatekeeping: Mothers' beliefs and behaviors that inhibit greater father involvement in family work. Journal of Marriage and Family, 61, 199-112.

Almqvist, A-L. (2008). Why most Swedish fathers and few French fathers use paid parental leave: An exploratory qualitative study of parents. Fathering, 6, 192-200.

Beck-Gernsheim, E. (2000). Health and responsibility: From social change to technological change and vice versa In B. Adam, U. Beck \& J. Van Loon (Eds.), The Risk society and beyond. Critical issues for social theory (pp. 122-136). London: Sage.

Benson, L.G. (1968). Fatherhood: A Sociological perspective. New York, NY: Random House.

Brandth, B. (2012). Emotional dimensions of fathering and work-life boundaries. In P. McDonald \& E. Jeanes (Eds.), Men, wage work and family (pp. 114-128). London: Routledge.

Bruner, J. (1986). Actual minds, possible worlds. Cambridge: Harvard University Press.

Christiansen, S. L. \& Palkovitz, R. (2001). Why the "good provider" role still matters: Providing as a form of paternal involvement. Journal of Family Issues, 22, 84-106.

Coltrane, S. (2011). Household labour and the routine production of gender. In M. Kimmel, A. Aronson \& A. Kaler (Eds.), The gendered society reader. $2^{\text {nd }}$ Canadian edition (pp. 171-186). Don Mills, ON: Oxford University Press. 
Coltrane, S. \& Behnke, A. (2013). Fatherhood and family policies. In N.J. Cabrera \& C.S. Tamis-LeMonda (Eds.), Handbook of father involvement: Multidisciplinary perspectives, $2^{\text {nd }}$ Edition (pp. 419-437): New York, NY: Routledge.

Craig, L., \& Mullan, K. (2010). Parenthood, gender and work-family time in the United States, Australia, Italy, France and Denmark. Journal of Marriage and Family, 72, 1344-1361.

Dermott, E. (2008). Intimate fatherhood. A Sociological analysis. London: Routledge.

Dienhart, A. (1998). Reshaping fatherhood. The Social construction of shared parenting. Thousand Oaks, CA: Sage.

Doherty, W.J., Kouneski, E.F. \& Erickson, M.F. (1998). Responsible fathering: An overview and conceptual framework. Journal of Marriage and Family, 60, 277-292.

Doucet, A. (2006). Do men mother? Toronto: University of Toronto Press.

Doucet, A. (2009). Dad and baby in the first year: Gendered responsibilities and embodiment. The ANNALS of the American Academy of Political and Social Science, 624, 78-98.

Doucet, A. (2012). Gender equality and gender differences: Parenting, habitus, and embodiment. In L. Tepperman \& A. Kalyta (Eds.), Reading sociology. Canadian perspectives, $2^{\text {nd }}$ Edition (pp. 107-112). Don Mills, ON. Oxford University Press.

Doucet, A. (2013). Gender roles and fathering. In N.J. Cabrera \& C.S. Tamis-LeMonda (Eds.), Handbook of father involvement: Multidisciplinary perspectives, $2^{\text {nd }}$ Edition (pp. 297-319). New York, NY: Routledge.

Eerola, P. \& Huttunen, J. (2011). Metanarrative of the "new father" and narratives of young Finnish first-time fathers. Fathering, 9, 211-231. 
Eerola, P. \& Mykkänen, J. (2013). Paternal masculinities in early fatherhood: dominant and counter narratives by Finnish first-time fathers. Journal of Family Issues. OnlineFirst, DOI: $10.1177 / 0192513$ X13505566.

Forsberg, H. (2005). Finland's Families. In B.N. Adams \& J. Trost (Eds.), Handbook of world families (pp. 262-283). Thousand Oaks, CA: Sage.

Forste, R., Bartkowski, J.P. \& Jackson, R.A. (2009). "Just be there for them": Perceptions of fathering among single, low-income men. Fathering, 7, 49-69.

Fox, B. (2009). When couples become parents: The creation of gender in the transition to parenthood. Toronto: University of Toronto Press.

Frank, A.W. (2002). Why study people's stories? The dialogical ethics of narrative analysis. International Journal of Qualitative Methods, 1, 1-20.

Gatrell, C. (2007). Whose child is it anyway? The negotiation of paternal entitlements within marriage. The Sociological Review, 55, 352-372.

Griffin, P., Parpart, J. L. \& Zalewski, M. (2013). Introduction to the special issue: Men, masculinity, and responsibility. Men and Masculinities, 16, 3-8.

Haataja, A. (2009). Fathers' use of paternity and parental leave in the Nordic countries. Helsinki: The Social Insurance Institution of Finland. Retrieved from https://helda.helsinki.fi/bitstream/handle/10250/8370/FathersLeaves_Nordic.pdf?sequen $\mathrm{ce}=1$

Hyden, M. (2008). Narrating sensitive topics. In M. Andrews, C. Squire \& M. Tamboukou (Eds.), Doing narrative research (pp. 121-136). London: Sage.

Hänninen, V. (2004). A model of narrative circulation. Narrative Inquiry, 14, 69-85.

Jallinoja, R. (2006). Perheen vastaisku. Familistista käännettä jäljittämässä [The family strikes back. Tracing the familistic turn]. Helsinki: Gaudeamus. 
Jallinoja, R. (2008). Togetherness and being together. Family configurations in the making. In E.D. Widmer \& R: Jallinoja (Eds.), Beyond the nuclear family: Families in a configurational perspective (pp. 97-118). Bern: Peter Lang.

Kelle, U. (2007). The development of categories: Different approaches in grounded theory. In A. Bryant \& K. Charmaz (Eds.), The SAGE handbook of grounded theory (pp. 191214). Thousand Oaks, CA: Sage.

Korhonen, M. (1999). Isyyden muutos. Keski-ikäisten miesten lapsuudenkokemukset ja oma vanhemmuus. [The change in fatherhood. The childhood experiences of middle-aged men and their own parenthood] PhD Thesis. Joensuu: Joensuun yliopiston yhteiskuntatieteellisiä julkaisuja, no 39.

Lamb, M.E. (1997).The development of father-infant relationships. In M. E. Lamb (Ed.), The Role of the father in child development, $3^{\text {th }}$ Edition (pp. 104-120). New York: Wiley.

Lamb, M.E. (2010). How do fathers influence children's development? Let me count the ways. In M. E. Lamb (Ed.), The Role of the father in child development, $5^{\text {th }}$ Edition (pp. 1-26). New York: Wiley.

Lamb, M E., Pleck, J.H., Charnov, E.L., \& Levine, J.A. (1987). A biosocial perspective on paternal behavior and involvement. In J. B. Lancaster, J. Altaman, A. Rossi, \& R. L. Sherrod (Eds.), Parenting across the lifespan: Biosocial perspectives (pp. 11-42). New York: Academic.

Lammi-Taskula, J. (2006). Nordic men on parental leave: Can the welfare state change gender relations? In A.L. Ellingsæter and A. Leira (Eds.), Politicising parenthood in Scandinavia: Gender relations in welfare state (pp. 79-99). Bristol: The Policy Press.

Lammi-Taskula, J. (2008). Doing fatherhood: Understanding the gendered use of parental leave in Finland. Fathering, 6, 133-148.

LaRossa, R. (1988). Fatherhood and social change. Family Relations, 37, 451-457. 
LaRossa, R. (2012). Writing and reviewing manuscripts in the multidimensional world of qualitative research. Journal of Marriage and Family, 74, 643-649.

Lundqvist, Å. (2012). The gender equal father? The (welfare) politics of masculinity in Sweden, 1960-2010.In P. McDonald \& E. Jeanes (Eds.), Men, wage work and family (pp. 34-49). London. Routledge.

Marsiglio, W., \& Cohan, M. (2000). Contextualizing father involvement and paternal influence: Sociological and qualitative themes. Marriage \& Family Review, 29 (2), 75 95.

McDonald, P. \& Jeanes, E. (2012). Introduction. Locating men in the work-life nexus. In P. McDonald \& E. Jeanes (Eds.), Men, wage work and family (pp. 14-27). London. Routledge.

Miettinen, A. \& Rotkirch, A. (2012). Yhteistä aikaa etsimässä. Lapsiperheiden ajankäyttö 2000-luvulla. [Looking for family time. Families' time use in the 2000s.] Väestöntutkimuslaitos Katsauksia E42/2012. Helsinki: Väestöliitto.

Mikelson, K.S. (2008). He said, she said: Comparing mother and father reports of father involvement. Journal of Marriage and Family, 70, 613-624.

Miller, T. (2011). Making sense of fatherhood. Gender, caring and work. Cambridge: Cambridge University Press.

Morgan, D. (2011). Rethinking family practices. Houndmills: Palgrave Macmillan.

Morgan, D. (1996). Family connections. An introduction to family studies. Cambridge: Polity Press. 
Mykkänen J. \& Eerola, P. (2013). Isyyteen sitoutuminen ja isän vastuu esikoisisien kertomana [Father involvement and the responsibility of first-time fathers]. Kasvatus [The Finnish Journal of Education], 44, 17-29.

Nikander, P. (2008). Working with transcripts and translated data. Qualitative Research in Psychology, 5, 225-231.

O'Brien, M. (2009). Fathers, parental leave policies, and infant quality of life: International perspectives and policy impact. The ANNALS of the American Academy of Political and Social Science, 624, 190-213

O’Brien, M. \& Moss, P. (2010). Fathers, work and family policies in Europe. In M.E. Lamb (Ed.), The role of the father in child development. $5^{\text {th }}$ Edition (pp. 551-577). Hoboken, NJ: Wiley.

Palkovitz, R. (1997). Reconstructing "involvement": Expanding conceptualizations of men's caring in contemporary families. In A. Hawkins \& D. Dollahite (Eds.), Generative fathering: Beyond deficit perspectives (pp. 200-216). Thousand Oaks, CA: Sage.

Palkovitz, R. (2002). Involved fathering and men's adult development. Provisional balances. Mahwah, NJ: Lawrence Erlbaum.

Parsons, T. (1995). The American family: Its relations to personality and to the social structure. In T. Parsons \& R. Bales (Eds.), Family, socializations and interaction process (pp. 3-33). New York, NY: The Free Press.

Perälä-Littunen, S. (2007). Gender equality or primacy of the mother? Ambivalent descriptions of good parents. Journal of Marriage and Family, 69, 341-351.

Pleck, J. H. (2010). Paternal involvement: Revised conceptualization and theoretical linkages with child outcomes. In M. E. Lamb (Ed.), The Role of the father in child development, 5th edition (pp. 58-93). New York: Wiley. 
Pleck, J.H., Lamb, M.E. \& Levine, J.A. (1985). Facilitating future changes in men's family roles. Marriage and Family Review, 9 (3-4), 11-16.

Roy, K.M. (2006). Father stories: A life course examination of paternal identity among lowincome African American men. Journal of Family Issues, 27, 31-54.

Ruddick, S. (1995). Maternal thinking: Towards a politics of peace. $2^{\text {nd }}$ Edition. Boston, MA: Beacon.

Salmi, M. (2012). Leave policies development in Finland. In S. Parrukoski \& J. LammiTaskula (Eds.), Parental leave policies and the economic crisis in the Nordic countries. Seminar report (pp. 48-54). Helsinki: National Institute for Health and Welfare. Retrieved from http://www.thl.fi/thl-client/pdfs/c2223657-48f5-4e25-a9dbc532a15d6bcd

Shows, C. \& Gerstel, N. (2009).Fathering, class, and gender: A Comparison of physicians and emergency medical technicians. Gender \& Society, 23, 161-187.

Sigle-Rushton, W., Goisis, A. \& Keizer, R. (2013). Fathers and fatherhood in the European Union. In N.J. Cabrera \& C.S. Tamis-LeMonda (Eds.), Handbook of father involvement. Multidisciplinary perspectives (pp. 81-96). New York, NY: Routledge.

Sipilä, J., Repo, K., Rissanen T. \& Viitasalo, N. (2010). Cash-for-childcare: Unnecessary traditionalism or a contemporary necessity? In J. Sipilä, K. Repo \& T. Rissanen (Eds.), Cash-for-childcare. The consequences for caring mothers (pp. 21-45). Cheltenham, UK: Edward Elgar.

Smart, C. (2011). Close relationships and personal life. In V. May (Ed.), Sociology of personal life (pp. 35-47). Hampshire: Palgrave Macmillan.

Strauss, A. \& Corbin, J.M. (1998). Basics of qualitative research. Thousand Oaks, CA: Sage.

Townsend, N. (2002). Package deal: Marriage, work and fatherhood in men's lives. Philadelphia, PA: Temple University Press. 
Yoshida, A. (2012). Dads who do diapers: Factors affecting care of young children by fathers. Journal of Family Issues, 33, 451-477. 